\title{
Should the earned income tax credit rise for childless adults?
}

\section{The earned income tax credit raises income and work incentives among low-income parents but little goes to adults without children}

Keywords: employment, less-educated men, childless, low-income adults, non-custodial parents

\section{ELEVATOR PITCH}

The earned income tax credit provides important benefits to low-income families with children in the US. At an annual cost of about $\$ 60$ billion, it increases the incomes of such families while encouraging parents to work more by subsidizing their incomes. But low-income adults without children and non-custodial parents receive only very low payments under the program, providing them with little income benefits or work incentives. Many of these adults are low-income young men whose wages and employment rates have been declining for years and who might benefit substantially from expanded eligibility for the earned income tax credit.

\section{KEY FINDINGS}

\section{Pros}

๑ The earned income tax credit boosts income and work effort among low-income parents and contributed to the steep rise in employment among single mothers in the 1990s.

- Expanding the tax credit to low-income childless adults would raise income and work effort among a group whose earnings and employment have fallen substantially in recent decades and who now get little assistance from the program.

( The statistical evidence shows that work effort among low-income adults is sensitive to their net wages, and an earned income tax credit for childless adults would raise their net wages.

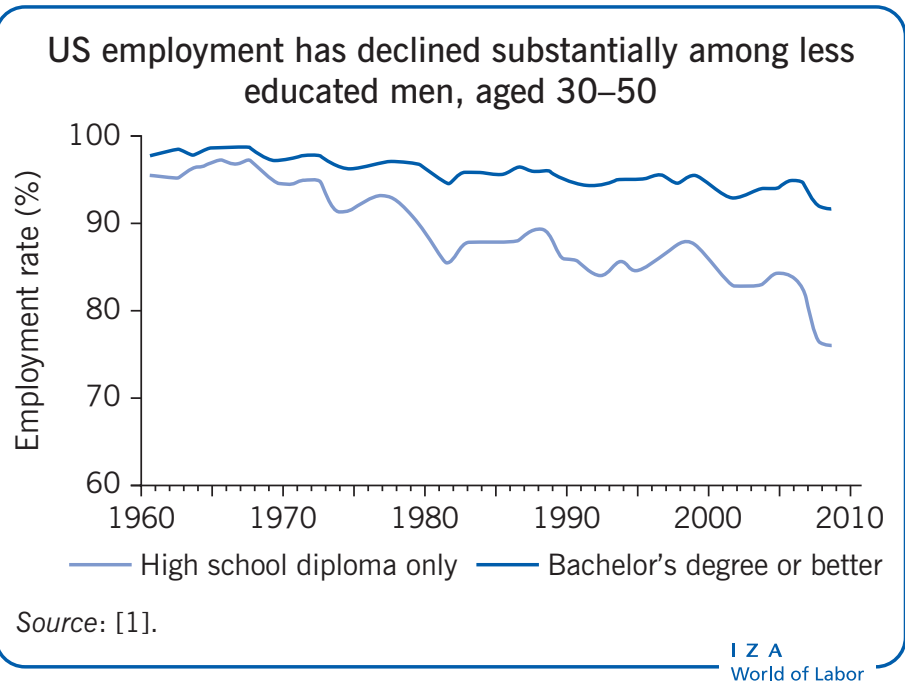

\section{Cons}

- The earned income tax credit costs about $\$ 60$ billion a year, and extending it to childless adults would add to those costs.

- Strong evidence is lacking on how effective such a program would be at raising income and employment among childless adults.

- Expanding the tax credit to childless low-income adults might discourage marriage and reduce work effort among childless adults whose credits are phasing out.

- Low-income men with child support orders or criminal records face additional barriers and disincentives in finding work and might need help to find and keep employment.

\section{AUTHOR'S MAIN MESSAGE}

Expanding the US's earned income tax credit to low-income childless adults and non-custodial parents, especially low-income men, would likely increase their earnings and work effort. This positive outcome might be more readily achieved if the federal government combined higher earned income tax credits for this group with additional workforce services or child support provisions, to improve the likelihood of their finding and keeping a job. Ultimately, the policy should include expansion of the tax credit among childless adults within a broader package of tax reforms, so that costs could be offset by revenue increases. 


\section{MOTIVATION}

Many industrial countries pay tax credits to workers with low earnings, which are designed to raise their incomes and encourage greater work effort. The earned income tax credit (EITC) in the US has succeeded in raising employment and earnings among low-income families with children, most of them headed by single mothers. But few benefits now go to low-income childless adults and non-custodial parents, especially men, whose earnings and employment rates have declined substantially in the last few decades-in fact, more than for any other demographic group [1]. The EITC for families with children enjoys political support from both of the major political parties in the US and has grown in generosity over time, during both Republican and Democratic administrations. Research offers strong evidence of positive impacts of EITC benefits, not only on the earnings and employment of parents but also on the educational attainment and other outcomes of their children. It is likely that expansion of the EITC benefits among childless adults would similarly boost their earnings and employment rates and increase child support payments made by low-income non-custodial fathers.

\section{DISCUSSION OF PROS AND CONS}

At least 17 OECD countries have instituted some form of EITC, also known as in-work tax credits. The tax credits almost always target workers with low employment rates and earnings or low family income, though they differ enormously in exactly who is eligible, whether minimum levels of earnings or hours worked are required for eligibility to receive the credit, its generosity, and whether and how it is phased in and out with rising earnings or income. The impacts on employment have been studied in Sweden, the UK, and the US, and almost all such studies find some positive effects on employment. But there are virtually no studies providing evidence on their impacts on low-income childless adults. In the US, there is one study of a state-level program for non-custodial fathers that finds some modest positive effects on their employment and child support payments.

\section{The earned income tax credit in the US}

The EITC is currently the largest public cash assistance program for poor families in the US. It began during the administration of Republican President Gerald Ford in 1975 and has been expanded several times since then under both Republican and Democratic administrations. It currently costs about $\$ 60$ billion a year at the federal level. A number of states supplement the federal credit with credits against state income taxes.

As a cash assistance program for the poor, the EITC has much greater political support than the program that is commonly referred to as "welfare" and is now known formally as Temporary Assistance for Needy Families (and previously as Aid to Families with Dependent Children). Both the population at large and economists generally prefer the EITC program to those welfare assistance programs. The reason is simple: welfare provides families with benefits if the parents are not working and reduces those benefits for each dollar earned above some minimal level (determined separately by each state). This payment calculation mechanism creates a disincentive to work, because the family's net earnings from working fall as welfare payments are phased out.

In contrast, parents receive nothing under the EITC if they are not working. For parents who are working, the EITC subsidizes their wages at a fixed rate up to an earning ceiling. The subsidy rate (as of 2015) is: $34 \%$ of earnings for families with one child, up to an income ceiling of 


\section{In-work tax credits in OECD countries}

US: earned income tax credit. The earned income tax credit is available to US workers on "low to moderate" incomes. To qualify, they must be aged 25-65, live in the US for at least half the year, and not be a dependent of another person; or have a child who meets certain requirements.

UK: working tax credit. Workers in the UK are eligible for the tax credit if they are over 25 , or aged $16-24$ and have a child or a qualifying disability. To qualify, they must work a certain number of hours of paid work each week (for example, 16 hours for a single person with children, or 30 hours for a single person without children), and have an income below a certain level (which varies depending on factors such as children and disability).

The basic amount of working tax credit is currently $£ 1,960$ a year, but applicants may receive more or less depending on circumstances and income.

New Zealand: in-work tax credit. New Zealand's in-work tax credit is one of several tax credits for families with children. Parents are eligible if they are normally in paid employment for at least 30 hours a week as a couple, or 20 hours a week as a single parent.

Parents with up to three children are eligible for a tax credit worth NZ\$60 a week. Parents with more than three children are eligible for an additional NZ\$15 a week.

Canada: working income tax benefit. Canada's working income tax benefit (WITB) is a refundable tax credit intended to provide tax relief for eligible working low-income individuals and families. Workers can claim WITB if their working income is over $C \$ 3,000$; if they are over 19; and if they are resident in Canada all year round. WITB is calculated based on marital status, province or territory of residence, income, eligible dependants, and disability benefit eligibility.

WITB is currently paid to individuals without children earning up to a maximum of $C \$ 17,986$, and to families earning up to $C \$ 27,736$.

Ireland: single person child carer tax credit; home carer tax credit. Ireland offers a range of tax credits applicable in different circumstances. For example, the single person child carer tax credit awards $€ 1,650$ a year to single parents.

The home carer tax credit applies to couples in a marriage or civil partnership where one partner is a home carer and cares for one or more dependent persons. To qualify, the home carer's income must be under $€ 5,080$ a year.

Finland: child tax credit. Finland awards tax credits to parents according to number of children and custody arrangements. It is currently $€ 100$ per child annually for single parents or $€ 50$ for parents with joint custody. The tax credit is reduced for parents whose income exceeds $€ 36,000$ a year.

The Netherlands: income-related combination tax credit. Working parents with children under 12 can apply for an income-related combination tax credit from the Netherlands Tax and Customs Administration. The tax credit means parents pay less in income tax and national insurance contributions. The amount of the credit is linked to parents' income.

Sources: US Internal Revenue Service. Online at: http://www.irs.gov/Credits-\&-Deductions/ Individuals/Earned-Income-Tax-Credit; UK Government. Online at: https://www.gov.uk/ working-tax-credit/overview; New Zealand Inland Revenue. Online at: http://www.ird.govt.nz/ wff-tax-credits/entitlement/what-is-wfftc/iwtc/wfftc-iwtc.html; Canada Revenue Agency. Online at: http://www.cra-arc.gc.ca/bnfts/wtb/menu-eng.html; Ireland Revenue. Online at: http:// www.revenue.ie/en/tax/it/leaflets/it1.html; Finnish Tax Administration. Online at: http://www. tax.fi/en-US/Individuals/Child_Tax_Credit_FAQ(35454); Government of the Netherlands. Online at: https://www.government.nl/topics/income-related-combination-tax-credit 
$\$ 13,000$ and a maximum credit of $\$ 3,300 ; 40 \%$ for families with two children, up to an income ceiling of about $\$ 19,400$ and a maximum credit of $\$ 5,548$; and $45 \%$ for families with three or more children, up to an income ceiling of about $\$ 20,000$ and a maximum credit of $\$ 6,242$ [2].

Thus, the EITC raises recipients' net wage income by $34-45 \%$ in families with children over the income range in which the EITC is phased in, which should induce recipients to work more, not less-as long as their work effort responds positively to their net wages (what economists call a positive labor supply elasticity). That appears to be the case for low-income single mothers [3]. For eligible wage earners whose federal income tax liability is less than the amount of the credit, the difference is refundable-meaning that the remainder of the credit is paid to the eligible family. To reinforce the positive effects of the EITC on work incentives, roughly $50 \%$ of US states have instituted their own earned income credits against state taxes.

Above the income ceiling for the EITC, the benefits phase out, potentially creating a disincentive to work just as the Temporary Assistance for Needy Families does. But the federal EITC has a very gradual phase-out, at the rate of about $20 \%$ per additional dollar earned, so that the marginal tax rate on earnings in this range is modest, to limit the work disincentive effect.

Indeed, the empirical evidence on the effects of the EITC on the earnings of low-income families with children-almost always headed by single mothers-is consistent with the predicted effects described above. Several studies have shown the positive effects of the EITC program on both the earnings and the employment rate of the household head. During the 1990s the EITC program was significantly expanded, at roughly the same time that a major welfare reform bill was passed restricting access to welfare benefits in a number of ways and transforming the Aid to Families with Dependent Children program into the Temporary Assistance for Needy Families program. The EITC expansion has been credited with raising the employment rates of single mothers by roughly three percentage points. There is some evidence of a negative effect on work during the phase-out of the benefit, but the negative effect on earnings during the phase-out is much smaller, perhaps just 1\% [4].

While it is possible, at least in theory, for the EITC to encourage marriage in some cases and to discourage it in others, the estimated effects on marriage are mostly small. But studies find other positive effects of the EITC-particularly on the wage growth of recipients (since they are gaining more work experience over time) and on the educational attainment and achievement of their children [2].

By raising the earnings of the poor, EITC benefits tend to reduce poverty and inequality in the US. There are other ways to accomplish this, such as raising the minimum wage at the federal or state level. Indeed, the Obama administration has proposed raising the federal minimum wage, and many states have recently raised their minimum wage. But many economists prefer an EITC increase to a minimum-wage increase. For one thing, the EITC clearly raises employment among the poor while a minimum-wage increase likely reduces it modestly. For another, as an antipoverty mechanism, the EITC is also much more narrowly focused on the poor and near-poor, while most of the beneficiaries of higher minimum wages are not from poor families, including middle-class youth and adults who happen to work at low-wage jobs [5].

But while the subsidy rate is $34 \%$ for families with one child, $40 \%$ for families with two children, and $45 \%$ for families with three or more children, low-income childless adults receive a subsidy rate of just $7.65 \%$-only enough to match their share of payroll tax payments-up to a maximum credit of just $\$ 500$. At this low subsidy rate, the current take-up rate among 
the target population of childless low-income men and women is quite low, and its effects on labor market outcomes are no doubt very limited.

\section{Should the EITC rise for childless men and women?}

Many proposals in the past few years have called for a substantial increase in the EITC for lowincome childless adults or for low-income adults who are non-custodial parents and paying their full child support order [6].

Low-income childless adults include both men and women, but men make up a larger share of this group, especially among people in their 20s and older. They tend to have low levels of education. Some low-income childless adults are non-custodial fathers of children who live with their mothers, while others (both men and women) might expect to become parents in future years. As noted above, wages among less-educated men have declined dramatically in recent years, much more than for any other demographic group (see Figure 1). Their rates of employment and participation in the labor market have fallen along with their wages. It is therefore quite puzzling that the demographic group in the US whose labor market opportunities have declined the most, and whose incentives to work have dropped accordingly, benefit the least from a program designed to encourage more work and higher earnings among the poor.

The situation among low-income non-custodial fathers is often particularly bleak. In many cases, judges issue child support orders by "default," or without any specific information about a non-custodial father's labor market prospects, which are often quite narrow. Employer demand for their services is especially weak if their skills are poor, their formal work experience is very limited, or they have a criminal record. For low-income non-custodial fathers who have had children with multiple women-a growing phenomenon often referred to as "complex families"-the sum of child support orders can become crushingly burdensome. If the father cannot make his payments, he falls into debt (arrears) to the state. If his family receives public assistance, many states will add the costs of these support programs to what the father owes. If he becomes incarcerated, the unmet orders continue to accumulate and the arrears grow. And, once a non-custodial parent is in arrears, the tax rate on his low earnings becomes quite steep-usually $50 \%$. If some of this money is distributed to the state (to pay the debt accumulated while the family was on public assistance), the incentive of the father to pay is further reduced. To get these fathers to pay, some states suspend their driver's license and eventually incarcerate them-both of which, in turn, can further reduce their earnings potential. Where enforcement of these provisions is limited, there are very strong incentives for the non-custodial parents to disappear from the formal labor market and work only sporadically and for cash [7].

One unanticipated consequence of any EITC program is to reduce overall wages, since the credit encourages more people to work at any wage. This reduction in wages especially hurts low-wage workers who are not eligible for much of an EITC benefit, such as childless adults and youths. This result creates a windfall for employers, who gain a third or more of the EITC benefits [8]. The drop in the wages of low-wage workers constitutes one more argument in favor of expanding the EITC program for childless workers, to offset the loss of income as a result of the lower wages caused by generous EITC payments to custodial parents. To prevent these wage reductions, some economists think that EITC increases should be accompanied by minimum-wage increases. According to this line of thinking, the EITC and minimum wage are complementary policies rather than substitutes, as was suggested above. 
Figure 1. US employment aged $30-50$

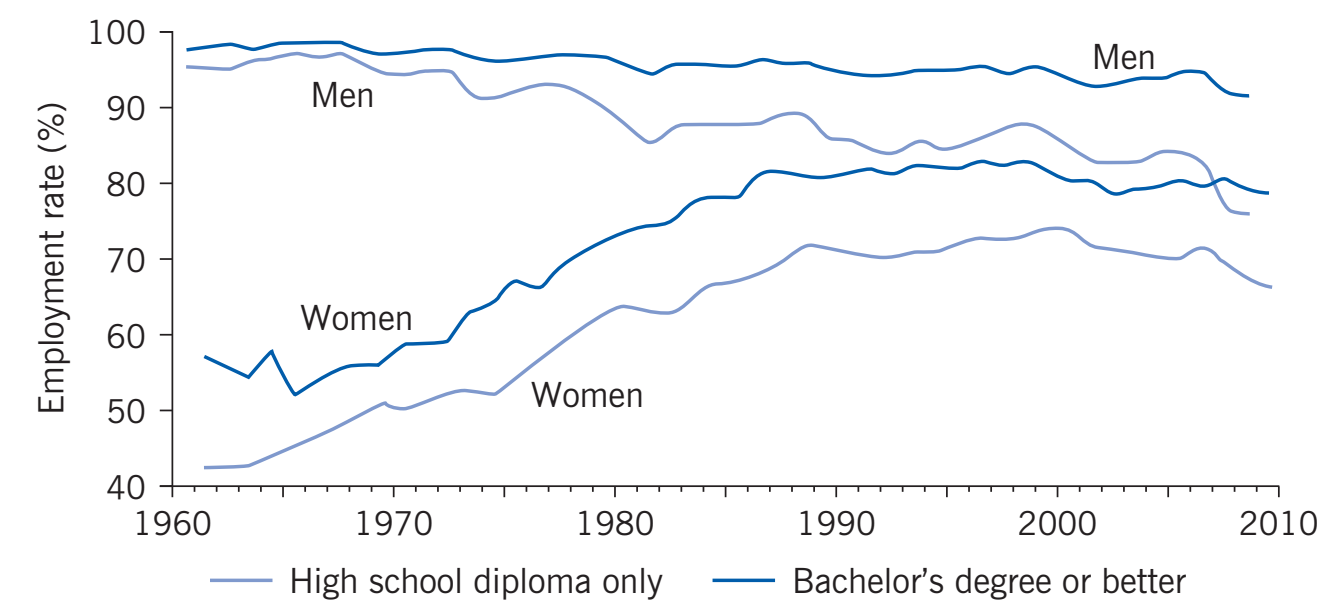

Source: Greenstone, M., and A. Looney. Trends: Reduced Earnings for Men in America. Washington, DC: The Brookings Institution, 2011 [1].

\section{Would raising the EITC for childless adults increase their employment?}

What might an expanded EITC program that is intended to encourage employment among the low-income childless population (including non-custodial parents) look like, and how would it compare with the generous EITC benefits received by low-income custodial parents of two or more children? The main design parameters that need to be considered are the subsidy rates, earnings ceilings, and phase-out rates.

Figure 2 compares the parameters of one proposal for higher EITC benefits for low-income childless individuals with the parameters of an EITC program for single parents with two children in 2014 [6]. This proposal would raise the credit for childless individuals to $25 \%$ of earnings, up to a maximum benefit of just over $\$ 1,600$. The benefit would phase out at a rate of just $16 \%$ and only after an individual has earned the federal minimum wage at year-round full-time work $(\$ 14,500)$; in other words, for each dollar earned above that level, the childless adult would give up 16 cents of their $\$ 1,600$ credit. These parameters were designed to be clearly less generous than those of the EITC for custodial parents but large enough to affect labor supply behavior and with a phase-in rate larger than the phase-out rate-all at a modest federal cost (estimated at about $\$ 12$ billion).

Would an expanded EITC program encourage more work among less-educated individuals in general and non-custodial parents in particular, especially men? While there has been little rigorous evaluation of such programs in the US or in other OECD countries, there are several reasons to believe that the effects could be beneficial. For one thing, estimated labor supply elasticities for this population are quite positive: roughly 0.3 to 0.4 for low-income men and a little lower for low-income single women [3].

In addition, results of an evaluation study using credible statistical methods are available for a state-level experiment with an expanded EITC program for non-custodial parents. Starting in 2006, the state of New York administered an expanded EITC program for non-custodial parents, offering up to $250 \%$ of the federal EITC benefit for low-income childless men and women (or more than $\$ 1,200$ ), as long as the non-custodial parent was fully up to date on child support payments for the year. Take-up rates were not very high. Statewide, less than $3 \%$ of non-custodial parents with a child support order received a credit $(9,600$ out of more 
Figure 2. How one proposal for an earned income tax credit for childless individuals C compares with the current program for single parents with two children

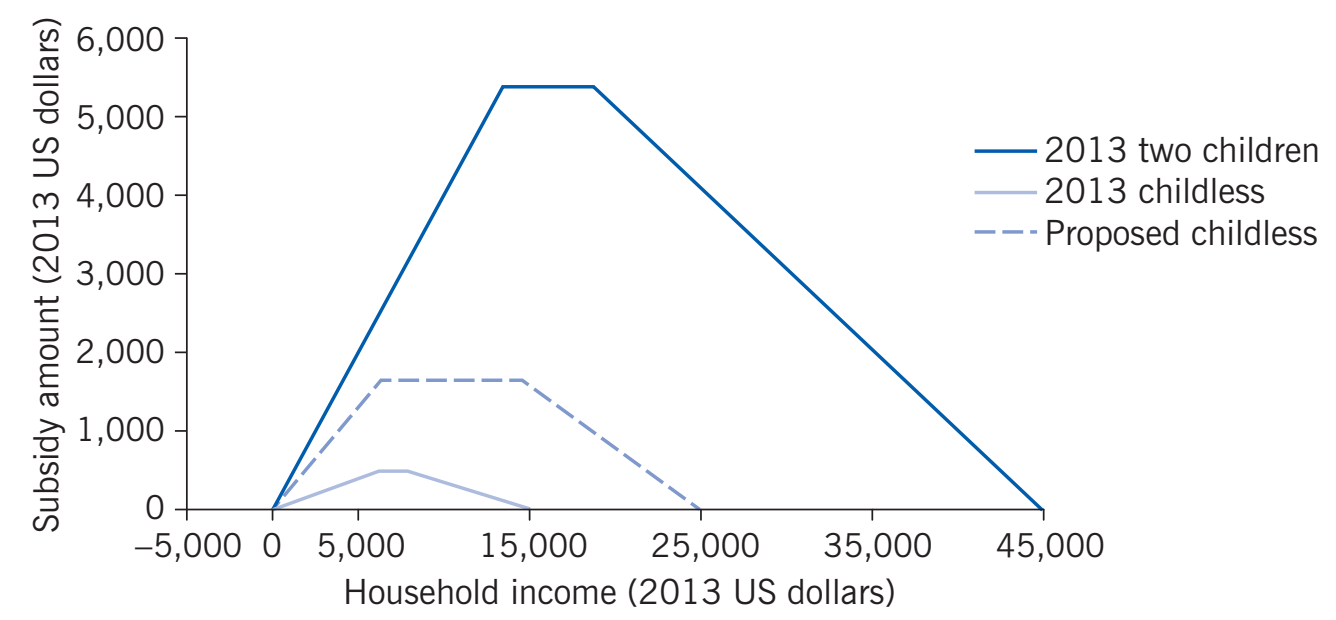

Source: Calculations from Internal Revenue Service rules.

than 350,000 ) in 2009. The low take-up rate may reflect the fact that many low-income men with child support orders do not file a tax return, did not fully pay their orders for the years of program availability, or were in arrears for previous years. Nevertheless, the study found positive impacts of 1-2 percentage points on employment and on child support payments for this population [9].

Starting in 2013, an experimental evaluation of a broader EITC expansion for childless adults is under way in New York City, to see whether these results can be replicated or improved. The program being evaluated, called Paycheck Plus, provides a sizable EITC benefit for all childless adults but is directed specifically to low-income men with a criminal record and those with child support orders. Evaluation results from this pilot will be able to inform any future federal or state efforts to expand EITC eligibility for childless adults and non-custodial parents [10].

\section{Some decisions to make about expansion of the EITC to childless adults and non-custodial parents}

In preparing to expand the EITC to childless adults and non-custodial parents, one of the first decisions to make is whether low-income childless adults should be broadly eligible or whether eligibility should be limited to non-custodial parents who are up to date on payment of their child support orders in a given year. The narrower EITC costs much less and targets the group that faces the worst market incentives to work right now: low-income non-custodial parents under a large child support order. For them, conditioning EITC benefits on staying current on the year's child support orders provides a strong incentive for doing so, along with the higher net wage income they would receive.

On the other hand, limiting such payments to non-custodial parents sends a message and creates an incentive that is troubling: a childless adult can become eligible for EITC benefits only by becoming a non-custodial parent. Positive incentives for non-custodial parents to meet their child support obligations can still be incorporated in a broader EITC for low-income childless adults simply by requiring them to be current on their payments in order to receive the benefit. Administratively, this requires the federal child support agency at the Department of Health and Human Services to forward to the Internal Revenue Service information about 
child support obligations and payments (which would be necessary under either proposal presented here). Furthermore, expanding the EITC to low-income childless adults is likely to benefit another group of children: those born in future years to adults who will have higher earnings at the time thanks to the additional work experience they accumulate in the meantime because of their EITC benefits. Accordingly, most proposals call for the broader program for all low-income childless adults rather than the narrower one limited to non-custodial parents.

Another issue to resolve is the age at which individuals would become eligible for the EITC. To reach low-income youth, especially young men who are at high risk of "disconnecting" from the worlds of school and work, one proposal calls for making individuals eligible at age 21 [6], which is younger than the eligibility for the current EITC program, which is age 25. Full-time college students would not be eligible. Information on college enrollment would have to be made available to the Internal Revenue Service from other sources to determine eligibility. And having the eligibility for childless adults begin at age 21 while that for custodial parents begins at 25 would create adverse incentives against custodial parenting.

Another concern is that adults who receive EITC benefits might be discouraged from marrying since that could jeopardize the EITC benefits one or both partners receive to an even greater extent than is now the case for custodial parents. The "marriage tax" feature of an EITC extension could be countered in a number of ways-such as by raising the income level at which the phase-out of the credit begins or by counting just half the income of the partner with the lower income when calculating tax liability for married joint filers.

\section{LIMITATIONS AND GAPS}

Despite the potentially positive effects on work and on the well-being of children of an EITC program for childless adults and especially low-income non-custodial parents, there are some important costs to be considered and some limitations on what is known about the effectiveness of the EITC in these circumstances.

For one thing, we do not know the extent to which low-income childless men would be affected by an expansion of the EITC, for several reasons. First, the EITC is designed as a remedy for weak incentives to work on the supply side of the labor market, whereas major barriers might exist on the demand side; for example, during times or in regions where the labor market is very weak or for people whom employers are reluctant to hire, such as men with criminal records. In addition, non-custodial parents in arrears on their child support might be eligible for the EITC if they fully meet their obligation in a given year, but their EITC benefits will be withheld and applied to cover their arrears, thus weakening their incentives to work or even file income tax returns. To encourage more non-custodial parents to participate, an EITC expansion might need to be accompanied by additional workforce services and perhaps some type of arrears management or forgiveness.

An additional concern about expanding the EITC program for childless adults and noncustodial parents is that it will exacerbate fraud and misreporting of income by potential recipients [11]. Currently, the Internal Revenue Service estimates that roughly a quarter of all EITC claims and payments, worth roughly $\$ 15$ billion a year, are fraudulent. This figure would likely rise with an expansion of the EITC program, though it is difficult with the information now available to predict by how much.

Perhaps the most important limitation is that the evidence on the potential impacts of an extension of the EITC program on worker behavior remains speculative, as there is not enough 
rigorous evaluation evidence for measuring such impacts. This is true in countries all around the world-for while there are a small number of studies estimating the effects of in-work tax credits in Sweden and the UK (in addition to those in the US), there is virtually no evidence on the target population of childless adults and non-custodial parents. It would be useful to have more city- and state-level experiments with the extension of the EITC program to childless adults and non-custodial parents that can be rigorously evaluated for their impact, such as the program implemented by New York state. Such experiments could yield valuable evidence on effectiveness that could inform decisions on how to proceed at the federal level.

\section{SUMMARY AND POLICY ADVICE}

Federal and state EITC payments to low-income parents with children have expanded dramatically in recent decades, with clear benefits to the poor in terms of higher income and work effort. But few jurisdictions extend much of these benefits to low-income childless adults and non-custodial parents, who are often less-educated men. Indeed, this group has suffered greater losses in wages and has responded with greater declines in labor force activity than any other major demographic group.

At a minimum, the federal or state governments should experiment with local extensions of EITC benefits to childless adults and non-custodial parents to generate more information through rigorous evaluation of the benefits and costs. Any experimental EITC should be large enough to incentivize changes in behavior toward work, child support payments, and tax filing. Major outreach efforts to low-income men might also be needed to generate sufficient take-up among those who currently avoid formal work and tax filing, along with additional workforce services, child support provisions, or help managing arrears.

But even without such additional evidence, there is now enough evidence to consider a major extension of the federal EITC program to childless adults and non-custodial parents should an opportunity arise as part of a broader federal tax reform effort involving a wide range of changes to tax rates and revenues. That evidence includes: the positive effects on work predicted by theory; the huge need to offset declining market wages for less-educated workers, especially men; the modestly positive results from the New York state experiment; and the bipartisan political support that such an effort seems likely to receive.

Other industrial countries where benefits from in-work tax credits accrue primarily to single mothers and their children should also consider experimenting with higher benefits for childless adults, to strengthen work incentives for less-skilled men.

\section{Acknowledgments}

The author thanks two anonymous referees and the IZA World of Labor editors for many helpful suggestions on earlier drafts.

\section{Competing interests}

The IZA World of Labor project is committed to the IZA Guiding Principles of Research Integrity. The author declares to have observed these principles.

(c) Harry J. Holzer 


\section{REFERENCES}

\section{Further reading}

Berlin, G. Testimony before Ways and Means Committee, Subcommittee on Income Security and Family Support, US House of Representatives, April 26, 2007.

Edelman, P., H. Holzer, and P. Offner. Reconnecting Disadvantaged Young Men. Washington, DC: Urban Institute Press, 2006.

\section{Key references}

[1] Greenstone, M., and A. Looney. Trends: Reduced Earnings for Men in America. Washington, DC: The Brookings Institution, 2011.

[2] Nichols, A., and J. Rothstein. The Earned Income Tax Credit. Berkeley, CA: University of California, 2015.

[3] Katz, L. "Wage subsidies for disadvantaged workers." In: Freeman, R., and P. Gottschalk (eds). Generating Jobs: How to Increase Demand for Less-Skilled Workers. New York: Russell Sage Foundation, 1998; pp. 21-53.

[4] Eissa, N., and H. Hoynes. "Taxes and the labor market participation of married couples: The Earned Income Tax Credit.” Journal of Public Economics 88:9 (2004): 1931-1958.

[5] Mankiw, N. G. "Help the working poor, but share the burden." The New York Times, January 4, 2014.

[6] Edelman, P., M. Greenberg, S. Holt, and H. Holzer. Expanding the EITC to Help More Low-Wage Workers. Washington, DC: Urban Institute, 2009.

[7] Mincy, R., M. Jethwani, and S. Klempin. Failing Our Fathers: Confronting the Crisis of Economically Vulnerable Nonresident Fathers. Oxford: Oxford University Press, 2014.

[8] Rothstein, J. "Is the EITC as good as an NIT? Conditional cash transfers and tax incidence." American Economic Journal: Economic Policy 2:1 (2010): 177-208.

[9] Nichols, A., E. Sorensen, and K. Lippold. The New York Noncustodial Parent EITC: Its Impact on Child Support Payments and Employment. Washington, DC: Urban Institute, 2013.

[10] MDRC. Paycheck Plus: Expanded EITC for Single Adults. New York: MDRC, 2015.

[11] Chetty, R., J. Friedman, and E. Saez. "Using differences in knowledge across neighborhoods to uncover the impacts of the ETC on earnings." American Economic Review 103:7 (2013): 26832721.

\section{Online extras}

The full reference list for this article is available from:

http://wol.iza.org/articles/should-earned-income-tax-credit-rise-for-childless-adults

View the evidence map for this article:

http://wol.iza.org/articles/should-earned-income-tax-credit-rise-for-childless-adults/map 